\title{
Challenges of Coordination in Provision of Urban Infrastructure for New Residential Areas: The Iranian Experience
}

\author{
Saeid Yazdani (Corresponding author) \\ Faculty of Design and Architecture, Universiti Putra Malaysia, Malaysia \\ E-mail: saeedyazdani110@yahoo.com \\ Kamariah Dola \\ Department of Landscape Architecture, Faculty of Design and Architecture \\ Universiti Putra Malaysia, Malaysia \\ E-mail: drkamariahupm@gmail.com
}

Mohammad Mehdi Azizi

School of Urban Planning, College of Fine Arts, University of Tehran

E-mail:mmazizi@ut.ac.ir

\author{
Johari Mohd Yusof \\ Department of Landscape Architecture, Faculty of Design and Architecture \\ Universiti Putra Malaysia, Malaysia \\ E-mail: jonhani02@yahoo.com
}

Received: November 5, 2014 Accepted: November 24, 2014

doi:10.5296/emsd.v4i1.6557 URL: http://dx.doi.org/10.5296/emsd.v4i1.6557

\begin{abstract}
Urban infrastructure provides foundations for modern civil community and enhances quality of life. Coordination between different urban infrastructure agencies plays a pivotal role in
\end{abstract}


the success of provision of these critical facilities. In turn, identifying and managing interdependency between different urban infrastructures is a key issue in establishing robust coordination in the process of the provision of urban infrastructure. To this end, the present paper, by reviewing the pertinent literature and investigating the current coordination context of urban infrastructure provision in Iran, provides a conceptual framework for identifying the roots of coordination challenges in this salient domain of urban knowledge. The interdependency between urban infrastructure and complexity of the urban infrastructure provision, two significant features of urban infrastructure provision, are two highlighted points in the framework.

Keywords: Urban infrastructure provision, Coordination, Interdependency, Complexity

\section{Introduction}

Urban Infrastructure systems are the pillars and backbone of cities, provisioning mobility, lodging, energy, potable water, sanitation, and communications. Infrastructure plays a pivotal role in any development, because without it development will not occur (Porter, 1986). Urban infrastructure is often in the foreground when we discuss about city development and the quality of life of the urbanites. Good quality and sufficient infrastructure are vital elements of prosperity of any nation. In the absence of urban infrastructure, land has little potential for residential, commercial, industrial and other kinds of land uses. Urban Infrastructure plays a salient role in shaping urban space, determining where inhabitants live, work and create wealth; how they move; and how they exchange or sell their goods. The influence of urban infrastructure on city development, function, management, and growth over the short, medium, and long time has been frequently emphasized (see, for example, Azizi, 2000; Boyle et al., 2010; Ausbel \& Herman, 1988; Cotton \& Franceys, 1994; Seitz, 1995; Seitz \& Licht, 1993).

Lack of urban infrastructure is a good catalyst for squatter formation and worsening housing conditions in urban districts. In other words, the presence or absence of these essential facilities is one major difference between a slum dweller and a non-slum dweller areas (Otegbulu \& Adewunmi, 2009). To this end, it is important to provide adequate infrastructure to inhabitants, especially in the housing area. In line of this, Abrams (1964) points out that housing is not just shelter, it depends upon many facets of economic activity, industrialization, and urban infrastructure development. Urban infrastructure can affect growth through many channels (Agénor \& Moreno-Dodson, 2006). For instance, one percent increase in infrastructure stock result in one per cent increase in Gross Domestic Product (World Bank, 1994). In addition to its function of raising the Gross Domestic Product (GDP), infrastructure contributes to the welfare of households and quality of life (Kessides, 1993; Sanford Bernhardt \&McNeil, 2008). Moreover, there is an undeniable relation between provision of urban infrastructure and social justice. In confirmation of this notion, Calderón and Servén (2010) point out that increasing the quantity and quality of infrastructure results in reducing social inequality.

Urban infrastructure systems are interconnect facilities, including public utilities (power, piped gas, telecommunications, water supply, sanitation and sewerage, and solid waste 
management), municipal works (roads and drainage) and transport sectors (public transit, ports and airports). The term infrastructure, which is defined as "the underlying foundation or basic framework (as of a system or organization)" (MerriamWebster's Collegiate Dictionary, 1993) implies systems which are highly interconnected and mutually dependent in complex ways, both physically and through a host of information and communications technologies (Rinaldi et al., 2001). In the other words, what happens to one of urban infrastructure systems can directly and indirectly influence other infrastructures, influencing large district of cities. Therefor, to achieve sustainable urban infrastructure, those involved in the urban infrastructure provision, which will be referred as "UI-provision" in this paper, must consider the interaction between infrastructure systems (Engel-Yan et al., 2005). Hence, coordination between urban infrastructure agents, which will be referred as "UIAs" in this article, is an essential key factor for providing reliable urban infrastructure for new development areas.

UI- provision is a prolonged process involving financing, construction and renovation that involve a multitude of agents $(\mathrm{Wu}, 1999)$. Coordination between these different agents is a major challenge that affects the process of provision of urban infrastructure worldwide. As Linn (1983) points out lack of coordination, financing and undesirable physical characteristics of new areas are major problems found in the provision of urban infrastructure for new development areas. In line with this, Sohail et al. (2005) stress that overlap of responsibility, duplication of functions, and lack of coordination between different UIAs are common constraints for UI-provision in developing countries. To wit, because of the multi-faceted, multi-level and cross-jurisdictional nature of urban infrastructure, coordination between UIAs is an essential factor to achieve prosperity in the provision of these critical facilities. Notwithstanding this undeniable fact, in most developing countries, such as Iran, urban infrastructures are not treated as interconnected systems but rather being designed and constructed independently.

In Iran the responsibilities and authorities of the three main stages of urban infrastructure provision (Planning, Financing and Implementation) are dispersed among several organizations, both vertically and horizontally. This fragmentation of responsibility and authority has limited the inter-sectoral relationships and coordination between different UIAs (Hejazi, 2003). In Iran, like other developing countries, lack of coordination between different UIAs in the context of infrastructure provision for new development areas causes numerous problems such as overlapping and duplication of activities (Khan, 1997), failure in meeting project deadlines (Panday \& Jamil, 2010) and so forth. Thus, establishing a robust coordination between different UIAs is one of the necessary factors for successful provision of urban infrastructure.

To date, most of the urban infrastructure-related studies focused on the investment of infrastructure provision (Suen, 2005). Despite of the interrelated nature of urban infrastructure (Hudson et al., 1997; Engel-Yan et al., 2005; Benedict \& McMahon, 2002; Rinaldi et al., 2001) and as well as the substantial need for inter-organizational collaboration in UI-provision (Ittissa, 1991; Sohail et al., 2005), very few efforts have been devoted to understanding the role and related challenges of inter-organizational coordination in 
UI-provision. To this end, this paper is an initial step towards addressing this research gap by providing a conceptual framework, and empirical evidences from Iranian experiences in the context of UI-provision for new development areas.

The structure of this paper is as follows. The next section covers urban infrastructure provision- related literature. Then, in section 3, a conceptual overview of coordination is presented. The essence of coordination in the context of UI-provision has been argued in section 4. In section 5, from a coordination perspective, an analytical discussion of the process of UI- provision in Iran is presented. Finally, discussion and conclusion are presented in section 6 and section 7, respectively.

\section{Provision of Urban Infrastructure}

The notion of urban infrastructure is a general concept, covering a range of structures required for the continuation of urban life. In an overall classification, urban infrastructure can be categorized into Green Urban Infrastructure and Built Urban Infrastructure. In contrast with built urban infrastructure the concept of green urban infrastructure has been coined. Green urban infrastructures are urban's natural life support system- an interconnected network of river, woodlands, wetlands, and other natural areas; greenways, natural parks and other conservation lands; farms and ranches; and other open spaces that support native species, maintain natural ecological processes, sustain air and water resources and contribute to the health and quality of life for communities and citizens (Benedict \& McMahon, 2006).

Built urban infrastructure, in turn, can be classified into two Main categories, social urban infrastructure and physical urban infrastructure. Social urban infrastructure includes education, health, security, bank, law and order, fire fighting, financial institution, housing and other services (Love et al., 2011; Flora, 1998). The term social (urban) infrastructure was first used by Swanson (1996). This term implies that these kind of urban structures operates in a parallel way to physical urban infrastructure. On the other hand, physical urban infrastructure, or most familiar as "urban infrastructure", are combined and interconnected networks that provide essential public services such as public utilities (power, piped gas, telecommunications, water supply, sanitation and sewerage, and solid waste management), municipal works (roads and drainage) and transport sectors (public transit, ports and airports) (World Bank, 1994; Hudson et al., 1997; Rinaldi et al., 2001).

Urban infrastructure systems provide the foundation for economic growth and quality of life. Feldman et al. (1988) points out that a robust and vibrant urban infrastructure is vital to the continued prosperity of any urban community. In the other words, in the absence of urban infrastructure, land has no potential for any kind of urban developments. In the line with this, Porter (1986) argues that infrastructure is a pivotal factor for any development, because without it development will not occur. Engel-Yan et al. (2005) stress that to achieve sustainable urban design at any level, those involved in urban design process must consider the unique role of urban infrastructure in urban shaping. Therefore, it can be purported that provision of urban infrastructure is prior to any urban development activities.

The provision of urban infrastructure is highly complicated and extremely intricate process 
(Sözüer \& Spang, 2012). The complex nature of UI-provision can be derived from several factors. These kind of urban sub-systems are interconnected and mutually dependent in complex ways (Rinaldi et al., 2001; Little, 2002; Heller, 2001; Amin, 2002). In the other words, what occurs to one of urban infrastructures can directly and indirectly affect other infrastructures. Another factor caused complexity in the provision of urban infrastructure is involving of a multitude of players (Wu, 1999) in multi level of decision making. Various stakeholders involved in infrastructure provision make the process of the provision of them too intricate. According to Sözüer and Spang (2012), provision of urban infrastructure can be affected by deficiencies resulting from organizational shortcomings including coordination and communication problem among administrative units. Thus, considering interdependency between urban infrastructure systems and pertinent organizations is one of the key issues in improving urban infrastructure provision.

The provision of urban infrastructure, on the other hand, is a prolonged and time consuming process. Wu (1999) argues that UI-provision a lengthy process involving financing, construction and maintenance that may involve a multitude of players. The life cycle of urban infrastructure projects covers a long-lasting period of time from the conception to utilization. In German, for instance, given the scale of these projects, the UI-provision can last up to 12-20 years (Sözüer \& Spang, 2012). In line with this, Herder et al. (2011) argue that urban infrastructure projects are implemented over several years, sometimes decades. However, several factors make UI-provision to be a prolonged process. These factors can be enumerated as complexity of planning regulation and approval process; hardly manageable regulations; organizational shortcoming including lack of coordination and cooperation among and between different government agencies; land acquisition and etc.

Provision of urban infrastructure, moreover, is a high cost process and often suffering from deficiencies in cost recovery (Wu (1999). According to Word Bank report (1991) scarcity of financial resources and low technical capacity has resulted in widespread insufficiencies in urban infrastructure provision. These shortcomings impose extensive burdens on urban activities, inter alia, industry, commerce, residential and recreational activities. In light of this, Sohail et al. (2005) stress that one of privilege constraints for UI-provision is lack of resources, including money, skills, technology, trained personnel and so forth. Moreover, the final project cost of the majority of urban infrastructure projects, worldwide, exceed the anticipated cost. It is identified that only $40 \%$ of all projects, including urban infrastructure projects, achieve their stipulated cost and $50 \%$ of these projects exceed their budgeted costs by $40 \%$ to $200 \%$ (Hartmann \& Ashrafi, 2004). Financing of urban infrastructure projects, however, is one of the main concerns of experts and scholars who are involved with UI-provision.

With respect to the significance of financial aspects in UI-provision, various financing methods pertained to infrastructure provision have been presented by urban scholars. Azizi (1995) identifies three different ways to urban infrastructure investment, including traditional public expenditure; private-sector participation; and user-pay system. It is assumed that user-pays policies play significant roles in enabling dwellers in new residential areas to benefit from urban infrastructure (Azizi, 2000). Researches show that urban infrastructure is 
expected to be more cost-effective and has desirable impacts on urban milieu when it is subject to user charges based on provision cost and readiness to pay (Kessides, 1993). In the line with this, Wu (1999) points out that user charge systems are essential to guarantee efficient use of urban infrastructure. Furthermore, the absence of such user-pay systems often leans to trim down the quantity and quality of UI-provision. However, Pethe and Ghodke (2012) stress on finding new financial methods like "municipal-bonds" for financing urban infrastructure. Likewise, they argue that the success of this initiative instrument is subject to the existence of a thick and secondary market in the urban infrastructure section. Parenthetically, it is indispensable to insure that all costs pertinent to UI-provision are affordable for the target groups (Cotton \& Francey, 1994).

Hence, because of high investment and technical expertise needed for UI-provision; the prolonged project life-cycle; the difficult legal problems of acquiring rights-of-way across private lands; and the considerable economies of scale present in large-scale construction projects, nearly all analyses of UI-provision demonstrate that UI-provision is better to be performed in public sectors (see, for example, World Bank, 1994; Ostrom, 1996). Almost in all countries, all around the world, these public responsibilities and authorities are dispersed among divers government agencies. Therefore, with respect to the interconnected nature of urban infrastructure (Engel-Yan et al., 2005; Benedict \& McMahon, 2006), there is a substantial need for coordination between and among different government agencies involved in UI-provision. That is why, in the absence of inter organizational coordination, in the context of UI-provision, numerous problems would occur, inter alia, overlap and duplication of activities; failure in meeting project deadlines; increase in the cost urban infrastructure projects; creates chaos, confusion, discord and friction among urban infrastructure agencies (UIAs); and so forth (Panday \& Jamil, 2010; Khan, 1997). In the following section, an overview of coordination is presented.

\section{Coordination: a Conceptual Overview}

\subsection{Existing Literature on Coordination and Coordination Theory}

Coordination has been defined in Merriam-Webster dictionary as "the harmonious functioning of parts for effective results". In another famous dictionary, Shorter Oxford English Dictionary, coordination refers to "the action of coordinating; harmonious combination of agents and functions towards the production of a result" (cited in Robinson et al., 2000). Probably the first formal definition of coordination has been offered by Lindblom (1965). He defines coordination as a systematic relationship between decisions, which include positive outcomes for participants and avoidance of negative consequences. Later scholars offered to some extent different definition for coordination. For instance, Curtis (1989) defines coordination as "Activities required to maintain consistency within a work product or to manage dependencies within the workflow". Minear (2002) argues "coordination is multilayered, involving the orchestration of relationships, not only at headquarters, but also at the regional, national and field levels". One of the latest coordination definitions is the way through which structure and functioning of organizations can be described and analyzed (Christensen \&Lægreid, 2008). The variety of these 
definitions demonstrates the complication of defining coordination as well as the diversity of potential starting points for studying this abstract concept. Consistent with this, Hossain and $\mathrm{Wu}$ (2009) point out that coordination is an abstract concept which is hard to be defined from a quantitative standpoint. However, the most cited definition of coordination is "the management of dependencies among activities" (Malone \& Crowston, 1994).

From a terminological point of view, despite differences between the definition of coordination, collaboration, cooperation and competition, there are some meaning dependencies between them. Womack et al. (1991) argue that there are two different forms of cooperation. Cooperation, in some situation, can be a shape of collaboration between partners (collaborators) in which each has the equivalent decision-making capacity and acts with others towards a common goal. Co-designing in the automotive sector, for instance, can be considered as cooperation form of collaboration. On the other hand, cooperation can as well be a form of coordination and a synchronization of operation carried out by independent actors (Malone \& Crowston, 1990). For example, coordination among different UIAs in the context of infrastructure provision for new development areas can be considered as a later form of cooperation. In the same way, although terms like "collaboration", "competition" and "cooperation" each has their own implication, managing dependencies between activities is a significant part of each of them (Malone \& Crowston, 1994). For example, peers working together on an intellectual attempt being referred to collaboration; competition typically means that one actor's gains are another's losses; and sharing goals among different actors is defined as cooperation. However, it can be advantageous to consider all these words as describing different approaches to manage dependencies among activities, that is, as different forms of coordination.

The concept of coordination has been investigated in a range of different academic disciplines, including business processes, organization science, urban studies, economics, artificial intelligence, product development and so forth (Olson et al., 2001). In these various fields coordination has been applied to address specific types of problems. To organization science, for instance, coordination refers to the management of dependencies between activities and organizations (Alexander, 1993). In the artificial intelligence-related literature, this term is used to study the interaction of autonomous agents (see, for example, Panait \& Luke, 2005; Durfee, 2001; Wooldridge, 2002). On the other hand, coordination in economics implies making mutually steady decisions. Finally, in urban-related sciences, coordination refers to administering the interactions between and among the organizations involved in implementation of urban development plans (see, for example, Panday \& Jamil, 2010; Tornberg, 2012).

Several authors, from different academic disciplines, have suggested theory on coordination, inter alia, Turoff (1983); Winograd and Flares (1986); Malone (1988); Conklin and Begeman (1988); Holt (1988); Curtis (1989); Malone and Crowston (1991); Singh (1992); and Crowston et al. (2006). But the most cited coordination theory has been posed by Malone and Crowston (1990 \& 1994). They describe coordination theory as "the act of managing interdependencies between activities performed to achieve a goal." Four main components of this theory are: Goals, Activities, Actors and Interdependencies. From their point of view, 
among these four components, "managing interdependency" is the most important factor for establishing a robust coordination between different organizations. That is why, if there is no interdependence, there is nothing to be coordinated. In the light of this, several scholars stress on the role of interdependencies in inter-organizational coordination (see, for example, Hart \& Estrin 1990; Roberts \& Gargano 1989; Crozier, 2012; Scott, 2003; Panchal, 2010; Tornberg, 2012). However, in general, there are three kinds of interdependencies: Prerequisite, Shared resources and Simultaneity.

\subsection{Different Kinds Coordination}

In coordination-related literature, several different kinds of coordination can be identified. Klein and Orsborn (2009) present two distinct forms of coordination, "concatenate coordination" and "mutual coordination". A three-basic type of inter-organizational coordination has been posed by Alexander (1995), "solidarity-associations coordination", "structures - markets coordination" and "hierarchies coordination". Trust and shared goals are foundation of solidarity-associations. In solidarity-associations framework, coordination is not through an exchange of resource, rather due to mutual responsibility among participants. An example of solidarity-associations coordination, with respect to the scope of the study, is coordination among different UIAs in the context of infrastructure provision for new development areas. On the other hand, in structures-markets framework coordination between autonomous and self-interested agents are through mutual adjustment on the basis of information on demand, supply, and prices. Coordination between the housing sector and different UIAs in the context of infrastructure provision can considered as an example of the structure- markets coordination. Finally, coordination in a hierarchical framework is based on lined governance with different level of control and authority. For instance, coordination between different level of organization, national, provincial and city level, in the process of urban infrastructure can be considered as an example of hierarchies coordination.

From another perspective, coordination can be classified into centralized coordination and decentralized coordination. In centralized coordination, the overall aims of the system are broken down into subsystem goals and corresponding activities by a central authority who process system-level knowledge (Panchal, 2010). In contrast, in decentralized coordination, individual goals and activities as well as the interaction between them drive the overall outcomes of the system. In other words, a decentralized coordination mechanism can be considered as a formal entity aimed to represent a system for organizing and coordinating activities (Hurwicz \& Stanley, 2006). There is a third scenario between centralized and decentralized coordination framework called hybrid coordination. Hybrid coordination can be obtained through a combination of centralized and decentralized coordination. However, due to the basically diverse nature of the provision of urban infrastructure, the centralized coordination mechanisms are not effective in the UI-provision process. Thus, it can be postulated that decentralized coordination mechanisms are eligible and necessary.

According to Christensen and Lægreid (2008), coordination can also be classified into horizontal and vertical coordination. And each of them, in turn, could be classified into internal and external coordination. Horizontal Internal Coordination (HIC) is coordination 
within an organization between different units or department and at the same organizational level. Coordination between different departments of a ministry can be considered as an example of this type coordination. On the other side, Horizontal External Coordination (HEC) is coordination between different organizations at the same organizational level. For instance, coordination between and among different government agencies during the infrastructure provision process can be considered as this type of coordination. Similarly, vertical coordination has two branches, Vertical Internal Coordination (VIC) and Vertical External Coordination (VEC). In Vertical Internal Coordination (VIC) sub-ordinate units are coordinated and controlled by political and administrative leaders. On the other hand, Vertical External Coordination (VEC) means primarily coordination with super-national and multi-national organization, like the Organization of the Petroleum Exporting Countries (OPEC), where Iran and National Iranian Oil Company are in a subordinate position. However, in general, it can be noted that horizontal coordination is more network-based while the vertical dimension of coordination is more hierarchy-based (Verhoest \& Bouckaert, 2005).

Several kinds of coordination structures have been identified by Alexander (1993). In "Informal Network", as one of these coordination structures, coordination can be sustained through various types of links, inter alia, meetings, telephone calls, or correspondence to adhoc issue-related meeting between representatives of affected organization. "Inter-organizational Group", the second type of coordination structure, is the lowest levels of formal coordination. "Coordinator" is the third type of coordination structure. In this kind of structure an individual can be appointed whose (or major) function is to coordinate the activities of an interorganizational milieu. "The coordination unit", the fourth type of coordination structure, is formed primarily to coordinate and implement decisions within the relevant interorganiational system. "Non-administered Program" has been numerated as the fifth kind of coordination structure, in which the decisions of the units making up the relevant interorganizitional system are concreted by invoking an appropriate set of stimuli (Levine, 1972). The Sixth type of coordination structure is "Lead Organization", refers to an arrangement in which one organization is charged with the responsibility for coordinating activities of all relevant organizations in the organizational network. "Single Organization" is seventh structure identified by Alexander. The distinction between "Single Organization" and "Lead Organization" depends on the degree to which the functional range of relevant activities has been internalized. However, all of these coordination structures invoke formal and informal links, based on market (exchange), association-solidarity (trust), or hierarchy (command) (Alexander, 1998).

\section{The Essence of Coordination in Urban Infrastructure Provision}

Provision of urban infrastructure demand a great of coordination between government agencies at city, state and national level. This poses great challenges to those responsible for planning, financing and constructing at each level, who come to problems from different perspectives (Tornberg, 2010), experience different institutional barriers to policy integration 


\section{Mll Macrothink}

(Stead, 2008), and rely on different kinds of knowledge. By a way of explanation, coordination is a striking issue in UI-provision process because of the various interdependencies between and among different UIAs. Siddique (1994) enumerates several reasons for the importance of coordination between and among different local government organizations involved in the process. First, coordination can be applied for standardizing and optimizing services. Second, it could lead to the sharing and pooling of financial resources, experience and expertise. Third, coordination could pave the way for recognizing and resolving common problems. Fourth, it could stimulate joint projects. Finally, through coordinating together, urban infrastructure agencies would be able to handle their existing peripheral conditions.

Coordination is a significant issue in process of UI-provision because of the interdependencies within and amongst different urban infrastructure. In the other words, coordination is an important key enabler for success of UI-provision, since there is a large number of interdependent participants, different urban infrastructure agencies, involved in UI-provision process. In addition to interdependencies between urban infrastructures, the complexity of the urban infrastructure provision (Sanford Bernhardt \& McNeil, 2004; Amin, 2002; Heller, 2001; Little, 2002; Rinaldi et al., 2001) is another striking reason for the importance of coordination in UI-provision. To this end, in following sections these two prominent features of urban infrastructure provision are discussed.

\subsection{Urban Infrastructures are Interdependent Systems}

Urban infrastructure is defined as the framework of interdependent network, including institutions (comprising people and procedures), and distribution capabilities that provide a reliable flow of essential services and facilities. Several authors identified urban infrastructure (as of a system or organization) as a network of interdependent and interacted structures (see, for example, Hudson et al., 1997; Engel-Yan et al., 2005; Sanford Bernhardt \& McNeil, 2004; Rinaldi et al., 2001). For instance, Rinaldi et al. (2001) argue that infrastructures are highly interconnected and mutually dependent in complex ways. To wit, what occurs to one urban infrastructure can directly and indirectly influence other urban infrastructures. Chunlei et al. (2011), in parallel with this notion, point out that infrastructure systems are not only with huge scale, but also interconnected with each other. A sectoral stoppage of one urban infrastructure could result in a cascading failure for multiple interdependent infrastructures and trigger huge impact.

Urban infrastructure systems are connected at multifold point such that a bidirectional connection exists between the conditions of any given pair. Amin (2002) argues that when urban infrastructures have developed more complex to handle a range of demands, they have become more interdependent. Such as, links between electrical power and water supply, and as well as between power grid and telecommunication, gas pipelines, and transportation. This robust interconnection implies that an action in a part of one urban infrastructure network can ripple effects in the other infrastructure networks. In the other words, as Sanford Bernhardt and McNeil (2004) explain, the behavior of one of infrastructures, such as water supply or pavement, is influenced by other urban infrastructure systems, such as stormwater or 
electrical power, and also affects and constraints on them, including the plan, design and construction; the environment; and organizational, financial, and political system which directs them. Hence, any disturbances to one of highly interconnected urban infrastructures can hamper functions of other infrastructures.

In general, interdependencies between urban infrastructures can be classified into four main categories, physical, geographical, cyber, and logical (Rinaldi et al., 2001). Physical interdependency, in the urban infrastructure domain, resulted from a physical linkage between the input and output of two urban infrastructure agents, such that an output of one (e.g., electricity company) is a required input for another one (e.g., water company). Geographical interdependency implies a situation in which local environmental event can cause state changes in all of urban infrastructure systems. If the elements of multiple urban infrastructures be in close spatial proximity, this kind of interdependency will occur. Due to close spatial vicinity, for instance, physical damage to a part of a street can cause disturbances in water supply networks, electric power grids, and gas pipeline networks. On the other hand, an urban infrastructure has a cyber interdependency if its position relies upon information dispatched through information infrastructure, in the other words, urban infrastructures utilize electronic information and control system. Cyber interdependencies splice urban infrastructures to each other via informational links. Finally, logical interdependency links urban infrastructure agencies (UIAs) to one another in the absence of any direct physical, geographical, or cyber connection. Logical interdependency links urban infrastructure systems via human decisions such as financial markets.

All things considered, taking into account undeniable interdependencies between urban infrastructure (physical, geographical, cyber, and logical interdependencies), in the one side. And notice to this most cited notion "Coordination is managing dependencies"( Malone \& Crowston, 1994), on the other side. It can be concluded that coordination aspects play a pivotal role in the success of urban infrastructure provision. Therefore, with respect to the salient key characteristic of urban infrastructure (interdependency), an improvement in administration aspect of UI-provision demands collaboration and especially coordination between different UIAs.

\subsection{Urban Infrastructure as Complex System}

Urban infrastructure systems are complex, geographically dispersed, and interacting with each other and as well, with human beings as users, constructors, and operators (Amin, 2002). Urban infrastructures are more than just an aggregation of constituents; a collection of elements which are interacting with one another and the surrounding environment. Axelrod and Cohen (1999) point out that all urban infrastructures have one common property, they are all complex aggregations of interacting elements in which changes often happen as a result of their interaction. To date, several scientific authors hypothesis and claim that urban infrastructures are complex systems (see, for instance, Brown et al., 2004; Sanford Bernhardt \& McNeil, 2004; Amin, 2002; Little, 2002; Levinson \&Yerra 2006; Rinaldi et al., 2001; Yerra \& Levinson, 2005; \& Heller, 2001).

A complex system is known as a system which is built up by many autonomous but 
interconnected subsystems. Complex systems could not be illustrated by a single role and also their features cannot be limited to one level of explanation. They reveal attributes which come into light from the interaction of their components and which can not be forecasted based on the properties of their individual subsystems. Bak (1996) points out that this kinds of systems exhibit "emergent behavior", resulting from the interactions among system components that cannot be explained exclusively by the sum of the individual component behaviors. For instance, water supply system does not function as an isolated system, but rather as networks (providing potable water for consumers) are interacting with other urban infrastructure, like electric grids as well as with human beings as constructors, operators and users. These networks also exhibit significant variability in the context of service quality, inter alia, water pressure, water quality, and quantity of supply. In consistence with this notion, Amin (2002) emphasizes that a major source of complexity in complex systems is the interdependency between its subsystems, as such the interdependence of the power grid and the telecommunication networks.

Complex systems have precisely been characterized by John Holland (1988), a pioneer in the field. In Holland's notation, these characteristics are: Firstly, many subsystems (autonomous agents) with outspread control. For instance, in the domain of urban infrastructure, these autonomous agents are: systems' user; water companies; electricity companies; and etc. Secondly, multiplicity of organizational levels. For instance, city, provincial, national organizations are the commonly recognized organizational levels in infrastructure systems. Thirdly, the capability of subsystems (agents) to adapt. For instance, urban infrastructure agents (UIAs) adapt to the situation of urban infrastructure and resources at their disposal (Sanford Bernhardt \& McNeil, 2004). Finally, the utilization of internal models to forecast the future. As such, forecasting the future needs of each of urban infrastructures by pertinent planners. In addition to above mentioned complexity characteristics of the infrastructure, Chunlei et al (2011) numerate some more characteristics for urban infrastructure as a large-scale complex system: (1) Multi-level, infrastructure cover all aspects of social life, involving energy, potable water, power, transportation, etc. Moreover, each facility can be divided into subsystems; (2) Openness. Infrastructures are open systems, exchanging material, information, and energy with one another and the external environment; (3) Multi-component, many categories of facilities are involved in infrastructures; (4) Dynamic non-equilibrium, they have the dynamic characteristic and as well, continuity features; and (5) Nonlinear, in urban infrastructure, any elements can influence other elements, and be affected by other factors at the same time.

To sum up, considering the complexity nature of urban infrastructure system, in one side, and involvement of human beings in urban infrastructure provision (Sanford Bernhardt, 2004), on the other side, it can be concluded that coordination is a core aspect in UI-provision. In the light of this fact, Kjenstad (1998) and Rota (1998) argue that there is a vital need for coordination in complex cooperative systems (like urban infrastructure provision), especially among the partners (different urban infrastructure agencies). Moreover, involvement of human being in UI-provision (as system provider, operators, and users) exacerbates the need for coordination in this process (Mintzberg, 1993). Therefor, coordination is an essential 


\section{Macrothink}

mechanism through which disparate urban infrastructure agencies (UIAs) come together with the intention of making their efforts in the context of UI-provision more compatible (in terms of efficiency, effectiveness and equity).

\section{The Coordination Context of Urban Infrastructure Provision in Iran}

Provision of urban infrastructure is prior to any real estate development since without it land has no potential for any kind of urban land uses. These fundamental urban structures provide shelter, mobility, delivery of energy, portable water, communications and so forth. In Iran, like other developing countries, UI-provision has mostly been done by the government sector. The governmental planning paradigm in Iran adheres to the sectoral model, where urban infrastructure agencies (often vertically linked to national level entities) are set up at town or city level to serve their functions and services (Hejazi, 2003). In Iran, several government agencies (under the jurisdiction of different ministries) as well as municipality departments are involved in UI-provision.

Table 1 summerized the role and responsibility of different government agencies and municipal departments involved in UI-provision in Iran. For example, as shown in Table 1, in spite of physical and geographical interdependencies between water supply networks and streets, these two critical infrastructures are provided, in an isolated environment, by "Water \& Waste Water Eng. Co." and "Department of Technical \& Development of the municipality", respectively. Furthermore, these two apart organizations are under jurisdiction of two ministries, ministry of power and ministry of the interior, respectively. As an another example, despite of logical and geographical interdependencies between electricity grid, natural gas pipeline and housing sector (some scholars such as Abrams, 1964; \& Osman, 2012 consider housing as one kind of urban infrastructures), these facilities are separately provided by "Electrical Distribution Co.", "Gas Company" and "Department of Building \& Housing", respectively. These three mentioned organization are under jurisdiction of three separate ministries, Ministry of Power, Ministry of Oil and Ministry of road \& Urban Development, respectively. 


\section{Macrothink}

Table 1. The Role and Responsibilities of Relevant Organization in Urban Infrastructure in Iran

\begin{tabular}{|c|c|c|}
\hline Ministry & Agency/Organization & Role and responsible relevant to urban infrastructure \\
\hline Ministry of the Interior & $\begin{array}{l}\text { Municipality / } \\
\text { Department of Technical } \\
\text { and Development }\end{array}$ & $\begin{array}{l}\text { - Design and construction of streets } \\
\text { - Design and construction of surface water collection } \\
\text { systems } \\
\text { - Street Maintenance } \\
\text { - Feasibility study and financial analysis (Mansoor, 2004) }\end{array}$ \\
\hline Ministry of Power & $\begin{array}{l}\text { Water and wastewater } \\
\text { Eng. Co. }\end{array}$ & $\begin{array}{l}\text { - Design \& construction of water supply and transmission } \\
\text { system } \\
\text { - Design \& construction of wastewater collection and } \\
\text { transmission systems } \\
\text { - Design and construction of water treatment plant } \\
\text { - Design and construction of wastewater treatment plant } \\
\text { - Operation and maintenance water supply and } \\
\text { transmission systems } \\
\text { - Operation \& maintenance wastewater collection and } \\
\text { transmission systems } \\
\text { - Feasibility study and financial analysis (Qanoon-e } \\
\text { Tashkil-e Sherkat-hay Ab wa Fazelab, 1991). }\end{array}$ \\
\hline Ministry of Oil & Gas Company & $\begin{array}{l}\text { - Design \& construction of natural gas distribution } \\
\text { system } \\
\text { - Operation \& maintenance of natural gas distribution } \\
\text { system } \\
\text { - Feasibility study and financial analysis (Sharh-e } \\
\text { Vazayef-e Sherkat-e Melli Gaz, 2006). }\end{array}$ \\
\hline Ministry of Power & $\begin{array}{l}\text { Electrical } \\
\text { Co. }\end{array}$ & 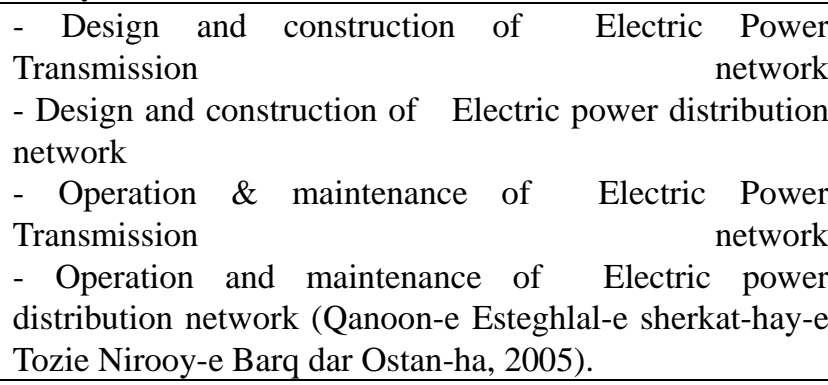 \\
\hline $\begin{array}{l}\text { Ministry of road and } \\
\text { Urban Development }\end{array}$ & $\begin{array}{l}\text { Department of Building } \\
\text { \& Housing }\end{array}$ & $\begin{array}{l}\text { - Preparation and implementation of plans and programs } \\
\text { for housing (Qanoon-e Taqir-e Nam-e Vezarat-e Abadani } \\
\text { wa Maskan be Vezarat-e Maskan wa Shahrsazi, 1974). }\end{array}$ \\
\hline $\begin{array}{lr}\text { Ministry of } \\
\text { Communications and } \\
\text { Information } \\
\text { Technology }\end{array}$ & $\begin{array}{l}\text { Telecommunication } \\
\text { company }\end{array}$ & $\begin{array}{l}\text {-Preparation and implementation of plans for } \\
\text { Telecommunication networks (Qanoon-e Vazayef wa } \\
\text { Ekhtiyarat-e Vezarat-e Ertebatat wa Fanavari Etelaat, } \\
\text { 2003). }\end{array}$ \\
\hline
\end{tabular}

These kind of centralized and sectoral planning, financing and implementation systems do not allow urban infrastructure agencies to properly access other agencies' information, and participate in the overall process planning and implementation of urban infrastructure systems. The institutional multiplicity and fragmentation of UI-provision responsibilities at the central level act as obstacles to coordination in the process of UI-provision (Madanipour, 1998; Zebardast, 2005).

In pertaining literature, as mentioned above, several diverse methods have been devoted to UI-provision. But three phases are common in all of them, Planning, Financing and 


\section{Mll Macrothink}

Implementation (Liu, 2004). In Iran, the responsibilities and authorities of these three phases, as illustrated in Table 2, are dispersed among several organizations, both vertically and horizontally. In the other words, the separation of planning, financing and implementation is a common feature of UI-provision frameworks in Iran. For instance, as shown in Table 2, planning and design of street networks, by means of providing master and detailed urban development plans, are within the authorities and responsibilities of Ministry of Road and Urban Development (MRUD), while municipalities are in charge of financing and implementation of these kind of urban infrastructure projects. These fragmentation and competition for resources and authorities result in limited cross-sectoral collaboration, and subsequently, lack of coordination between UIAs in the context of UI-provision for new development areas (Hejazi, 2003).

However, the coordination mechanisms, being applied in the context of UI-provision in Iran, are not sufficiently effective. In Iran, two coordination structures are mainly used for coordinating different urban infrastructure agencies, "Informal Network" and "Inter-organizational Group". In the former structure, urban infrastructures agencies coordinate, not sufficiently, their activities, in the context of UI-provision, by means of telephone calls, mutual meeting, and correspondence to ad hoc issue-related meeting between representatives of affected organization. In the form of latter structure, there being a commission at provincial level, in Iran, called "Commission of Detail Plan" or more famous as "Commission of Article 5". This commission is comprised of representatives from different organizations, including urban infrastructure agencies, and chaired by the governor-general or his deputy. Despite of this fact that the mission of "commission of article 5 " is not merely coordinating different urban infrastructure agencies, to somewhat this commission can play a significant role in coordinating infrastructure agencies, especially in planning phase of the UI-provision. 
Table 2. Who Does What for Urban Infrastructure Projects in Iran

\begin{tabular}{|l|l|l|l|}
\hline & \multicolumn{1}{|c|}{ Planning } & \multicolumn{1}{|c|}{ Financing } & \multicolumn{1}{|c|}{ Implementation } \\
\hline Urban Street Network & $\begin{array}{l}\text { Ministry of road and Urban } \\
\text { Development } \\
\text { Or/And } \\
\text { Municipality }\end{array}$ & $\begin{array}{l}\text { Municipality } \\
\text { Or/ And } \\
\text { Central } \\
\text { Government }\end{array}$ & Municipality \\
\hline $\begin{array}{l}\text { Surface Water Collection } \\
\text { Systems }\end{array}$ & Municipality & $\begin{array}{l}\text { Municipality } \\
\text { Or/ And } \\
\text { Central } \\
\text { Government }\end{array}$ & Municipality \\
\hline $\begin{array}{l}\text { Water Supply and } \\
\text { Transmission System }\end{array}$ & $\begin{array}{l}\text { Water and wastewater Eng. } \\
\text { Co. }\end{array}$ & $\begin{array}{l}\text { Central } \\
\text { Government } \\
\text { Or/ And } \\
\text { Users (directly } \\
\text { and indirectly) }\end{array}$ & $\begin{array}{l}\text { Water and wastewater Eng. } \\
\text { Co. }\end{array}$ \\
\hline $\begin{array}{l}\text { Wastewater Collection and } \\
\text { Transmission Systems }\end{array}$ & $\begin{array}{l}\text { Water and wastewater Eng. } \\
\text { Co }\end{array}$ & $\begin{array}{l}\text { Central } \\
\text { Government }\end{array}$ & $\begin{array}{l}\text { Water and wastewater Eng. } \\
\text { Co. }\end{array}$ \\
\hline $\begin{array}{l}\text { Natural Gas Transmission and } \\
\text { Distribution System }\end{array}$ & Gas Company & $\begin{array}{l}\text { Central } \\
\text { Government }\end{array}$ & Gas Company \\
\hline $\begin{array}{l}\text { Electric Power Transmission } \\
\text { and Distribution Network }\end{array}$ & Electrical Distribution Co. & $\begin{array}{l}\text { Central } \\
\text { Government }\end{array}$ & Electrical Distribution Co. \\
\hline Housing project & $\begin{array}{l}\text { Department of Roads and } \\
\text { Urban Development }\end{array}$ & $\begin{array}{l}\text { Central } \\
\text { Government } \\
\text { (Granting loans) } \\
\text { Or/ And } \\
\text { Users }\end{array}$ & $\begin{array}{l}\text { Department of Roads and } \\
\text { Urban Development }\end{array}$ \\
\hline Telecommunication networks & $\begin{array}{l}\text { Telecommunication } \\
\text { Government }\end{array}$ & $\begin{array}{l}\text { Telecommunication } \\
\text { Company }\end{array}$ \\
\hline
\end{tabular}

\section{Discussion}

It is substantiated, with respect to the above discussion, that there is barely any formal coordination structure for ensuring sound coordination between different UIAs in the context of UI-provision, in Iran. In the other words, provision of urban infrastructure suffers from lack of Horizontal External Coordination (HEC). A number of factors are responsible for lack of coordination amongst UIAs. First, the current centralized planning system limits information sharing between different UIAs, and as well does not allow them to participate in the planning and implementation process of overall UI-provision (Madanipour, 1998). Second, organizational diversity and fragmentation of responsibilities of UI-provision at the central level in Iran both act as barriers for ensuring coordination between UIAs (Zebardast, 2005). Third, competition among the urban infrastructure agencies restricts their coordination. Forth, sectoral model, where agencies are mostly linked to the national institutions, limits relationship between UIAs at local levels (Hejazi, 2003). Last but not least, different kind of organizational structures and accountability (in Iran there is an evident distinction between municipalities' management and other UIAs, municipalities are administrated by city councils while others are directly controlled by national entities) affect the coordination between different agencies who are involved in UI-provision.

Lack or poor coordination between different UIAs creates a number of problems. Failure in meeting urban infrastructure-related project deadlines can be one these shortcomings (Panday 
\& Jamil, 2010). The other ones are overlapping and duplication of activities. These shortcomings cause many development projects, like housing development projects, to remain incomplete and abandon in the middle stage of their development (Khan, 1997). On the other hand, missing projects' deadline results in increasing projects' cost, creating chaos, discord and friction among various agencies involved in the projects. In a word, lack of coordination in the context of UI-provision result in "bad-implementation" of urban infrastructure-related projects (Panday, 2006). Following example illustrates how lack of coordination between different UIAs, in Iran, affects the success of new housing development areas.

"Mehr" scheme is a wide government housing program aimed to provide housing for low-income people in Iran. This scheme is based on Cooperative Economics Law of Iran, and as well inspired by principles of 43 and 44 of the Constitution of Islamic Republic of Iran (Arvand Kalhor et al., 2013). The "Mehr" housing scheme, launched in 2007, is aimed to achieve these goals: providing housing for homeless people with priority to low-income strata; and provision of residential land with the help of Housing and Urban Development Organization for members in the form of 99-year lease contract (Seelig, 2011; Iran's Ministry of Cooperation, 2008). In the recent decades, "Mehr housing projects have been considered as serious government policies in the housing sector (Research Center of Iran's economy, 2002). However, because of coordination challenges and also some other factors, which are beyond the scope of the present discussion, this mass production of housing does not achieve to desired goals, in some parts of Iran (Arvand Kalhor et al., 2013). To exemplify, two "Mehr" housing projects, which have been suffered from coordination challenges in the context of UI-provision, are presented in the following paragraphs.

"Parand Mehr Schemes Housing" is one of the "Mehr"schemes housing projects located in Prand New Town (PTN), a New Town next to Tehran. According to PTN-development manager's report (cited in http://www.asriran.com, in Persian, retrieved November 28, 2012) there are 4000 uninhabited-"Mehr" residential units in PTN, just because of not provision of urban infrastructure for them. Another example of coordination challenges in the context of infrastructure provision is "Shirin Shahr Mehr Housing" case located in Shirin Shahr New Town (SSNT), a New Town in south of Iran. Based on SSNT-development manager's report (cited in http://www.mehrnews.com, in Persian, retrieved May 7, 2013) because of not provision of urban infrastructure in this New Town, 6300 "Mehr" residential units are not ready for residing housing applicants. Thus, lack of coordination between UIAs can be considered as one of the major barriers for success of housing development projects in Iran.

\section{Conclusion}

The preceding discussions allow us to draw the conclusion that coordination in the process of the provision of urban infrastructure for new residential areas is essential, that is why it brings to gather independent UIAs to make their endeavors more harmonious in the interest of efficiency, effectiveness and equity. From this point of view, inter-agency coordination is of the topmost prerequisite when different government agencies seek to provision infrastructure for new residential areas, in Iran. The reason for this is that when several institutions are 
required to act together to accomplish specific objectives, coordination challenges may occur, to wit, the various Agency's activities and jurisdiction areas of UIAs may overlap. The results from the analysis of the UI-provision process in Iran show that this process suffers from lack of coordination, especially inter-government agency coordination, during all three phases of UI-provision, financing, planning, and implementation phase.

This paper, based on existing literature, presents a theoretical framework for dealing with coordination challenges in the context of the UI-provision. With respect to two exhibited features of UI-provision: (1) complexity feature of UI-provision; and (2) interdependencies between and among UIAs, which in turn exacerbates complexity feature, the framework highlights three key aspects of coordination challenge in the process of UI-provision: a) emergent behavior of UIAs in the context of UI-provision, b) various kinds of interdependencies between urban infrastructure, physical, geographical, cyber, and logical interdependencies, and c) multi levels of involved organizations. However, the studying of the process of UI-provision in Iran demonstrates that lack of attention to interdependencies, especially physical, logical and geographical interdependency, between UIAs is the influential cause of coordination problems in UI-provision.

With respect to the presented framework, on the one hand, and the capabilities of Agent-Based Modeling (ABM) approach in dealing with complex and interdependent systems, on the other hand, the future work would be developing an ABM in order to improve coordination between different urban infrastructure agencies (UIAs) in the context of provision infrastructure.

\section{References}

Abrams, C. (1964). Housing in the Modern World, Faber \& Faber, London.

Abrams, C. (1964). Housing in the Modern World, Faber\&Faber, London.

Agénor, P., \& Moreno-Dodson, B. (2006). Public Infrastructure and Growth: New Channels and Policy Implications. Policy Research Working Paper 4064. The World Bank, Washington, DC.

Alexander E. A. (1998). A structuration theory of interorganizational coordination: cases in environmental management. International Journal of organizational analysis, 6(4), 334-354. http://dx.doi.org/10.1108/eb028890

Alexander, E. R. (1993). Interorganizational coordination: Theory and practice. Journal of Planning Literature, 7(4), 328-343. http://dx.doi.org/10.1177/088541229300700403

Alexander, E. R. (1995). How organizations act together: Interorganizational coordination in theory and practice. Psychology Press.

Amin, M. (2002). Toward secure and resilient interdependent infrastructures. J. Infrastruct. Syst., 8(3), 67-75. http://dx.doi.org/10.1061/(ASCE)1076-0342(2002)8:3(67)

Arvand Kalhor, M., Esmailpour, H., \& Ahmadi, F. (2013). Evaluation the Performance of the Mehr Housing Project in Iran (Case Study Saqez City). Middle-East Journal of Scientific 
Research, 15(5), 707-711.

Ausbel, J., \& Herman, R. (Eds) (1988). Cities and Their Vital Systems: Infrastructure; Past, Present, and Future, Washingto n, DC: National Academy of Engineering.

Axelrod, A., \& Cohen, M. D. (1999). Harnessing Complexity: Organizational Implications of a Scientific Frontier. New York: Free Press, 32-61.

Azizi, M. M. (1995). The provision of urban infrastructure in Iran: An empirical evaluation. Urban Studies, 32, 507-522. http://dx.doi.org/10.1080/00420989550012942

Azizi, M. M. (2000). The User-pays System in the Provision of Urban Infrastructure: Effectiveness and Equity Criteria. Urban Studies, 37(8), 1345-1357. http://dx.doi.org/10.1080/00420980020080151

Bak, P. (1996). How nature works: The science of self-organized criticality, Springer, New York. http://dx.doi.org/10.1007/978-1-4757-5426-1

Benedict, M. A., \& Mc Mahon, E. T. (2002). Green infrastructure: smart conservation for the 21st Century. Renewable Resources Journal, 20(3), 12-17.

Benedict, M. A., \& McMahon, E. T. (2006). Green Infrastructure: Linking Landscapes and Communities. Washington, D.C., Island Press.

Boyle \& others (2010). Delivering Sustainable Infrastructure that Supports the Urban Built Environment, Environ. Sci. Technol. 2010, 44, 4836-4840. http://dx.doi.org/10.1021/es903749d

Brown, B., Neil-Adger, W., Tompkins, E., Bacon, P., Shim, D., \& Young, K. (2001). Trade-off analysis for marine protected area management. Ecological Economics, 37(3), 417-434. http://dx.doi.org/10.1016/S0921-8009(00)00293-7

Calderón, C. L., \& Servén (2010). Infrastructure and Economic Development in Sub-Saharan Africa, Journal of African Economies, forthcoming.

Christensen, T., \& Lægreid, P. (2008). The challenge of coordination in central government organizations: the Norwegian case. Public Organization Review, 8(2), 97-116. http://dx.doi.org/10.1007/s11115-008-0058-3

Chunlei, W., Lan, F., \& Yiqi, D. (2011). National Critical Infrastructure Modeling and Analysis Based on Complex System Theory. In Instrumentation, Measurement, Computer, Communication and Control, 2011 First International Conference on (pp. 832-836). IEEE. http://dx.doi.org/10.1109/IMCCC.2011.211

Conklin, J., \& Begeman, M. L. (1988). gIBIS: A hypertext tooling for exploratory policy discussion. In Tatar, D. (Ed.), Proceedings of the 2nd Conference on Computer-supported Cooperative Work (pp. 140-152). New York: ACM, 1988.

Cotton, A., \& Franceys, R. (1994). Infrastructure for the urban poor: policy and planning issues, Cities, 11, 15-24. http://dx.doi.org/10.1016/0264-2751(94)90045-0 
Crowston, K., Rubleske, J., \& Howison, J. (2006). Coordination theory and its application in HCI.

Crozier, M. P. (2012). Governing Codes: Information Dynamics and Contemporary Coordination Challenges. Administration \& Society. http://dx.doi.org/10.1177/0095399712461913

Curtis, B. (1989). Modeling coordination from field experiments. In Organizational Computing, Coordination and Collaboration: Theories and Technologies for Computer-Supported Work. Austin, TX, 1989.

Durfee, E. H. (2001). Scaling up agent coordination strategies. Computer, 34(7), 39-46, 2001. ISSN 0018-9162.

Engel-Yan, J., Kennedy, C., Saiz, S., \& Pressnail, K. (2005). Towards Sustainable Neighbourhoods: The Need to Consider Infrastructure Interactions, available at:www.nrca.org.

Feldman, R. D., Mudge, R., \& Rubin, K. I. (1988). Financin g Infrastr ucture Tools for the Future . New York: Executive Enterpris es, Inc.

Flora, J. L. (1998). Social Capital and Communities of Place1. Rural sociology, 63(4), 481-506. http://dx.doi.org/10.1111/j.1549-0831.1998.tb00689.x

Hart, P., \& Estrin, D. (1990). Inter-organization computer networks: Indications of shifts in interdependence. In Proceedings of the ACM Conference on Office Information S-vstems. ACM, New York. http://dx.doi.org/10.1145/91474.91491

Hartman, F., \& Ashrafi, R. (2004). Development of the SMARTTM Project Planning framework. Int. $\quad$ J. Project Manage 22(2004), 499-510. http://dx.doi.org/10.1016/j.ijproman.2003.12.003

Hejazi, S. J. (2003). Quality urban regeneration, co-ordinated professional leadership and integrated urban management in western Europe: Learning from Europeanexperience in relation to the Iranian context. Newcastle upon Tyne: Newcastle University.

Heller, M. (2001). Interdependencies in civil infrastructure systems. The Bridge, 31(4), 9-15, <http://www.nae.edu/nae/naehome.nsf/weblinks/KGRG-573PLA?OpenDocument> (June 17, 2003).

Herder, P. M., de Joode, J., Ligtvoet, A., Schenk, S., \& Taneja, P. (2011). Buying real options-Valuing uncertainty in infrastructure planning. Futures, 43(9), 961-969. http://dx.doi.org/10.1016/j.futures.2011.06.005

Holland, J. H. (1998). Emergence: From chaos to order. Reading, MA: Perseus.

Holt, A. W. (1988). Diplans: A new language for the study and implementation of coordination. ACM Transactions on Ofie I\$ormation Systems, 6(2). 109-125. 1988. http://dx.doi.org/10.1145/45941.45942 
Hossain, L., \& Wu, A. (2009). Communications network centrality correlates to organizational coordination, International Journal of Project Management, 27(8), November 2009, Pages 795- 811, ISSN 0263-7863, 10.1016/j.ijproman. 2009.02.003.

Hudson, W. R., Haas, R., \& Udding, W. (1997). Infrastructure Management, Integrating Design, Construction, Maintenance, Rehabilitation and Renovation, McGraw-Hill, New York, NY.

Hurwicz, L., \& Stanley, R. (2006). Designing Economic Mechanisms: Cambridge University Press. http://dx.doi.org/10.1017/CBO9780511754258

Ittissa, A. B. (1991). Towards a new philosophy on operation and maintenance. Waterlines, 10 21, 25-28. http://dx.doi.org/10.3362/0262-8104.1991.038

Kessides, C., (1993). The Contributions of Infrastructure to Economic Development: A Review of Experience and Policy Implications. Washington, DC: The World Bank, Discussion Paper No. 213. http://dx.doi.org/10.3362/0262-8104.1991.038

Kessides, C., (1993). The Contributions of Infrastructure to Economic Development: A Review of Experience and Policy Implications. Washington, DC: The World Bank, Discussion Paper No. 213. http://dx.doi.org/10.1596/0-8213-2628-7

Khan, M. M. (1997). Urban Local Governance in Bangladesh: An overview. In N. Islam \& M. M. Khan (Eds.), Urban governance in Bangladesh and Pakistan (pp. 7-26). Dhaka: Centre for Urban Studies.

Kjenstad, D. (1998). Coordinated supply chain scheduling. Ph.D. Thesis. Department of Production and Quality Engineering, Norwegian University of Science and Technology.

Klein, D. B., \& Orsborn, A. ( 2009). Concatenate Coordination and Mutual Coordination, Journal of Economic Behavior and Organization. http://dx.doi.org/10.1016/j.jebo.2009.05.003

Levine, R. A. (1972). Public planning: Failure and redirection. New York: Basic Books.

Levinson, D., \& Yerra, B. (2006). Self-organization of surface transportation networks. Transp. Sci., 40(2), 179-188. http://dx.doi.org/10.1287/trsc.1050.0132

Lindblom, C. E. (1965). The intelligence of democracy. New York: Free Press.

Linn, J. F. (1983). Cities in the Developin g World. New York: Oxford University Press.

Little, R. G. (2002). Controlling cascading failure: Understanding the vulnerabilities of interconnected infrastructures. J. of Urban Technology, 9(1), 109-123. http://dx.doi.org/10.1080/106307302317379855

Liu, Z. (2004). Planning and Policy Coordination in China's Infrastructure Development. Background paper commissioned for the ADB-JBIC-World Bank East Asia and Pacific Infrastructure Flagship Study.

Love, P. E. D., Lopez, R., Edwards, D. J., \& Goh, Y. M. (2011). Error Begat Error: Design 
Error Analysis and Prevention in Social Infrastructure Projects, Accident Analysis and Prevention.

Madanipour, A. (1998). Tehran: The making of a metropolis. Chichester, England: John Wiley.

Malone, T. V., \& Crowston, K. (1994).The Interdisciplinary Study of Coordination. ACM Computing Surveys, 26(1), March 1994.

Malone, T. W. (1988). What is coordination theory? (Working paper No. \#2051-88). Cambridge, MA: MIT Sloan School of Management.

Malone, T. W., \& Crowston, K. (1990). What is coordination theory and how can it help design cooperative work systems? In D. Tatar (Ed.), Proceeding of the Third Conference on Computer-supported Cooperative Work (pp. 357-370). Los Angeles, CA: ACM Press.

Malone, T. W., \& Crowston, K. (1991). Toward an interdisciplinary theory of coordination (Working paper No. 120): MIT Centre for Coordination Science.

Mansoor, J. (2004). Qavanin wa Mogharrat-e Marboot be Shahr wa Shahrdari (Laws and Regulations Related to Cities and Municipalities). Nashre Didar press.

Merriam Webster's Collegiate Dictionary (10th ed.), Springfield, MA, 1993.

Minear, L. (2002). The humanitarian enterprise: dilemmas and discoveries. Bloomfield: Kumarian Press.

Mintzberg, H. (1973). The Nature of Managerial Work. Harper \& Row.

Olson DC, White JA, Edelman L, Harkins RN, \& Kende H. (1991). Differential expression of two genes for 1 aminocyclopropane-1- carboxylate synthase in tomato fruits. Proceedings of the National Academy of Sciences, USA 88, 5340 \pm 5344. http://dx.doi.org/10.1073/pnas.88.12.5340

Osman, H. (2012). Agent-based simulation of urban infrastructure asset management $\begin{array}{llll}\text { activities. Automation in } & \text { Construction, } & \text { 45-57. }\end{array}$ http://dx.doi.org/10.1016/j.autcon.2012.06.004

Ostrom, E. (1996). Crossing the great divide: Coproduction, synergy, and development. World Development, 24, 1073-1087. http://dx.doi.org/10.1016/0305-750X(96)00023-X

Otegbulu, A., \& Adewunmi, Y. (2009). Evaluating the sustainability of urban housing development in Nigeria through innovative infrastructure management. International Journal of Housing Markets and Analysis, 2(4), 334-346. http://dx.doi.org/10.1108/17538270910992782

Panait, L. \& Luke, S. (2005). Cooperative multi-agent learning: The state of the art. Autonomous Agents and Multi-Agent Systems, 11(3), 387-434. http://dx.doi.org/10.1007/s10458-005-2631-2

Panchal, J. H. (2010). Coordination in Collective Product Innovation. ASME. 
Panday, P. K. (2006). Central-local relations, inter-organizational coordination and policy implementation in Urban Bangladesh. The Asia Pacific Journal of Public Administration, 28(1), 41-58. http://dx.doi.org/10.1080/23276665.2006.10779314

Panday, P. K., \& Jamil, I. (2010). Challenges of Coordination in Implementing Urban Policy: The Bangladesh Experience. Public Organiz Rev (2011) 11, 155-176. http://dx.doi.org/10.1007/s11115-010-0116-5

Pethe, A., \& Ghodke, M (2012). Funding Urban Infrastructure: From Government to Markets. Economic \&political weekly, 37(25), 2467-2470.

Porter D. R. (Ed.) (1986). Growth Management.The Urban Land Institute.

Qanoon-e Esteghlal-e sherkat-hay-e Tozie Nirooy-e Barq dar Ostan-ha. (2005). Retrieved May 31, 2013, from http://www.moe.gov.ir/Inner-Pages/MainNav/RulesRegulations/RuleDetail.aspx?RulesRegul ationID=1036.

Qanoon-e Taqir-e Nam-e Vezarat-e Abadani wa Maskan be Vezarat-e Maskan wa Shahrsazi va Taeen Vazayef-e An. (1974). Retrieved May 12, 2013, from http://rc.majlis.ir/fa/law/show/97102.

Qanoon-e Ttashkil-e Sherkat-hay Ab va Fazelab. (1991). Retrieved April 9, 2013, from http://www.moe.gov.ir/Inner Pages/MainNav RulesRegulations/RuleDetail.aspx? RulesRegulationID=1038.

Qanoon-e Vazayef wa Ekhtiyarat-e Vezarat-e Ertebatat wa Fanavari Etelaat. (2003). Retrieved May 21, 2013, from https://www.ict.gov.ir/fa/bishtar/laws/law/ministrylaw.

Rinaldi, S., Peerenboom, J., \& Kelly, T. (2001) Identifying, Understanding and Analyzing Critical Infrastructure Interdependencies, IEEE Control Systems Magazine, December,11-25. http://dx.doi.org/10.1109/37.969131

Roberts, K. H., \& Gargano, G. (1989). Managing a high reliability organization: A case for interdependence. In Managing Complexity in High Technology industries: Systems and People. Oxford University Press, New York, 147-159.

Robinson, D., Hewitt, T., \& Harriss, J. (Eds.). (2000). Managing development: Understanding interorganizational relationships. London: Sage Publications in Association with the Open University.

Rota, K. (1998). Coordination temporelle de centres ge'rant de fac son autonome des ressources-application aux chânes logistiques inte'gre'es en ae'ronautique. Ph.D. Thesis. University Paul Sabatier and ONERA, Toulouse, France.

Sanford Bernhardt, K. L. (2004). "An agent-based framework for modeling civil infrastructure systems management." Proc., Information Technology in Civil Engineering Symp., ASCE, Baltimore.

Sanford Bernhardt, K. L., \& McNeil, S. (2004). An agent-based approach to modeling the 
behavior of civil infrastructure systems. InPresentation at Engineering Systems Symposium. MIT.

Sanford Bernhardt, K. L., \& McNeil, S. (2008). Agent-Based Modeling: Approach for Improving Infrastructure Management. Journal of Infrastructure Systems, 14, 253-261. http://dx.doi.org/10.1061/(ASCE)1076-0342(2008)14:3(253)

Scott, W. R. (2003). Organizations: Rational, natural and open systems (5th ed.). New Jersey: Prentice Hall.

Seelig, S. (2011). A master plan for low carbon and resilient housing: The 35 ha area in Hashtgerd New Town, Iran. Cities, 28(6), 545-556. http://dx.doi.org/10.1016/j.cities.2011.06.001

Seitz, H. (1995). The productivity and supply of urban infrastructure. Regional Science (C), (August 1993), 121-141.

Seitz, H., \& Licht, G. (1993) The impact of the provision of public infrastructures on regional economic development in Germany. Regional Studies (forthcoming)

Sharh-e Vazayef-e Sherkat-e Melli Gaz. (2006). Retrieved April 21, 2013, from http:// www.nigc.ir/Site.aspx? Par tree=1110121A191D1212.

Siddique, K. (Ed.). (1994). Local government in Bangladesh. Dhaka: University Press Limited.

SINGH, B. (1992). Interconnected Roles (IR): A coordinated model. Tech, Rep. CT-84-92. Micro- electronics and Computer Technology Corp., Austin, Tex.

Sohail, M., Asce, M., Cavill, S., \& Cotton, A. P. (2005). Sustainable Operation and Maintenance of Urban Infrastructure: Myth or Reality ?, (March), 39-49.

Sözüer, M., \& Spang, K. (2012). Challenges in the Planning Process of Infrastructure Projects in Germany. Construction Research Congress 2012, 2369-2378. http://dx.doi.org/10.1061/9780784412329.238

Stead, D. (2008). Institutional aspects of integrating transport, environment and health policies, Transport Policy, 15, 139-148. http://dx.doi.org/10.1016/j.tranpol.2007.12.001

Suen, I. S. (2005). Residential development pattern and intraneighborhood infrastructure provision. Journal of urban planning and development, 131(1), 1-9. http://dx.doi.org/10.1061/(ASCE)0733-9488(2005)131:1(1)

Swanson, L. E. (1996). Social infrastructure and economic development. Pp. 103-19 in Rural Development Research: A Foundation for Policy, edited by Thomas D. Rowley, David W. Sears, Glenn L. Nelson,]. Norman Reid, and Mervin]. Yetley. Westport, CT: Greenwood Press.

Tornberg, P. (2010) Integration of land use and transportation planning under the canopy of a holistic plan? An argument for process around plans, Journal of Landscape Studies, 3(2-3), 


\section{Macrothink \\ Environmental Management and Sustainable Development \\ ISSN 2164-7682 \\ 2015, Vol. 4, No. 1}

147-157.

Tornberg, P. (2012). Committed to Coordination?: how different forms of commitment complicate the coordination of national and urban planning. Planning Theory \& Practice, 13(1), 27-45. http://dx.doi.org/10.1080/14649357.2012.649906

Turoff, M. (1983). Information, value, and the internal marketplace. New Jersey Institute of Technology, 1983.

Verhoest, K., \& Bouckaert, G. (2005). Machinery of government and policy capacity: The effects of specialization and coordination. In Painter, M., \& Pierre, J. (Eds.), Challenges to state policy capacity. Global trends and comparative perspectives. New York: Palgrave Macmillan.

Winograd, T., \& Flares, F. (1986). Understanding computers and cognition: A new foundation for design. Norwood, NJ: Ablex, 1986.

Womack, J. P., Jones, D. T., \& Roos, D. (1991). The Machine that Changed the World, Harper, Perennial, 1991.

Wooldridge, M. (2002). An Introduction to MultiAgent Systems. John Wiley and Sons Ltd, 2002.

World Bank (1991) Urban policy and economic development: an agenda for the 1990s, A World Bank policy paper. Washington, DC: The World Bank.

World Bank (1994). WDR 1994: Infrastructure for Development. World Bank and Oxford University Press. ISBN: 978-0-19-520992-1.

Wu, W. (1999). Reforming China's institutional environment for urban infrastructure provision. Urban Studies, 36, 2263-2282. http://dx.doi.org/10.1080/0042098992412

Yerra, B. M., \& Levinson, D. M. (2005). The emergence of hierarchy in transportation networks. Ann. Reg. Sci., 39(3), 541-553. http://dx.doi.org/10.1007/s00168-005-0230-4

Zebardast, E. (2005). Do plans matter? Managing a metropolis with two directives for more than a decade: The case of Tehran City. In International conference for integrating urban knowledge and practice, Gothenburg, Sweden.

\section{Copyright Disclaimer}

Copyright for this article is retained by the author(s), with first publication rights granted to the journal.

This is an open-access article distributed under the terms and conditions of the Creative Commons Attribution license (http://creativecommons.org/licenses/by/3.0/). 